Review

\title{
Targeting Bacterial Biofilms by the Green Tea Polyphenol EGCG
}

\author{
Regine Hengge \\ Institut für Biologie/Mikrobiologie, Humboldt-Universität zu Berlin, 10155 Berlin, Germany; \\ regine.hengge@hu-berlin.de; Tel.: +49-30-2093-49686
}

Academic Editor: Helieh S. Oz

Received: 13 May 2019; Accepted: 25 June 2019; Published: 29 June 2019

\begin{abstract}
Bacterial biofilms are multicellular aggregates in which cells are embedded in an extracellular matrix of self-produced biopolymers. Being refractory to antibiotic treatment and host immune systems, biofilms are involved in most chronic infections, and anti-biofilm agents are being searched for urgently. Epigallocatechin-3-gallate (EGCG) was recently shown to act against biofilms by strongly interfering with the assembly of amyloid fibres and the production of phosphoethanolamin-modified cellulose fibrils. Mechanistically, this includes a direct inhibition of the fibre assembly, but also triggers a cell envelope stress response that down-regulates the synthesis of these widely occurring biofilm matrix polymers. Based on its anti-amyloidogenic properties, EGCG seems useful against biofilms involved in cariogenesis or chronic wound infection. However, EGCG seems inefficient against or may even sometimes promote biofilms which rely on other types of matrix polymers, suggesting that searching for 'magic bullet' anti-biofilm agents is an unrealistic goal. Combining molecular and ecophysiological aspects in this review also illustrates why plants control the formation of biofilms on their surfaces by producing anti-amyloidogenic compounds such as EGCG. These agents are not only helpful in combating certain biofilms in chronic infections but even seem effective against the toxic amyloids associated with neuropathological diseases.
\end{abstract}

Keywords: bacterial biofilm; functional amyloid; curli fibre; bacterial exopolysaccharides; bacterial cellulose; chronic infection; antimicrobial

\section{Introduction}

Bacterial biofilms are ubiquitous multicellular aggregates which are usually attached to biotic or abiotic surfaces in which bacteria are embedded in an extracellular matrix of self-produced polymers [1-4]. Bacteria in biofilms are refractory to antibiotic treatment and host immune systems [5,6]. As a consequence, biofilms of pathogenic bacteria play crucial roles in chronic infections (e.g., of wounds, soft tissue and the urinary tract or in cystic fibrosis (CF), laryngitis, otitis media, dental plaque, caries and periodontosis) as well as in the colonization of catheters, artificial heart valves, orthopedic implants and other intracorporal medical devices [7,8]. Notably, this biofilm-associated antibiotic tolerance is not acquired by horizontal gene transfer or specific mutations in antibiotic targets as in classical antibiotic resistance, but it is part of the normal bacterial physiological and regulatory repertoire.

With biofilms being key to chronic infections, the need for anti-biofilm compounds has become apparent [8-11]. Unlike classical antibiotics, these are active at concentrations that do not interfere with bacterial growth or survival but inhibit the formation of bacterial biofilms or disrupt already existing biofilms by targeting biofilm-related structures or regulation. Thereby, they can act synergistically with antibiotics and/or allow the immune system to attack bacteria that would otherwise be hidden away in biofilms [9-13]. Screening large chemical libraries using high-throughput approaches has been used to identify anti-biofilm compounds [14]. Alternatively, natural products originating from plants, marine sponges or other biological sources have been tested [9,15-17]. The latter approach has 
revealed that numerous compounds, which naturally occur in plants, as well as complex plant extracts indeed exhibit anti-biofilm activity [18].

Epigallocatechin-3-gallate (EGCG) and related catechins, which are not only the major polyphenols in green tea (Camellia sinensis) but are also present in many other plants, have long been known to have numerous benefits for human health (see other articles in this compendium; for a review, see [19]). This also led to the first studies of EGCG's effects on bacteria almost 20 years ago. After a short introduction to biofims, this review will summarize reports on antimicrobial and above all anti-biofilm activities of EGCG with a focus on the more recent studies that have addressed the molecular mechanisms of action of EGCG. In addition, some bacterio-ecophysiological considerations will suggest that plants may be a highly valuable source of many more anti-biofilm agents for which EGCG may serve as a paradigm for the identification and analyses of mechanisms of action.

\section{Bacterial Biofilms}

The hallmark of bacterial biofilms is the presence of an extracellular polymeric matrix of complex and variable composition $[20,21]$. This matrix often literally encases the bacterial cells and confers structural stability, cohesion and elasticity to the biofilm, i.e., tissue-like properties, as most evident from the buckling, folding and wrinkling of colony biofilms that form large-scale three-dimensional morphological patterns [22-25]. Importantly, the matrix confers protection-for example, by trapping phages or antimicrobial compounds and preventing access of predators-and by binding water, it contributes to homeostatic conditions within the biofilm $[3,6,21,26]$.

Biofilm matrices contain secreted proteins, some of which can form amyloid fibres, exopolysaccharides and extracellular DNA, collectively termed extracellular polymeric substances (EPS) [21]. Exopolysaccharides, which differ in their monosaccharide constituents, chemical modifications, composition and types of glycosidic linkage, can be divided into two functional classes with either aggregative or water-binding mucoid properties. A widely occurring example of aggregative exopolysaccharides, which in general confer cohesion and structural stability to biofilms, is cellulose [27-29]. In biofilm matrices of Escherichia coli and many other bacteria, cellulose is present as a phosphoethanolamin-modified derivative (pEtN-cellulose) [30]. Other aggregative exopolysaccharides are Psl and Pel of Pseudomonas [31], VPS of Vibrio cholerae [32] or the exopolysaccharide of Bacillus subtilis [20]. Water-binding mucoid exopolysaccharides include colanic acid in enteric bacteria [33], alginate in Pseudomonas aeruginosa [34] or other capsule polysaccharides. Exopolysaccharides are synthesized by inner membrane-associated glycosyltransferases, which form the core of larger synthesis and secretion complexes that include additional chaperone and pore components in the cell envelope that guide the nascent polysaccharides to the cell surface [35]. Also, the pEtN group is transferred to cellulose during its transit through the periplasm of E. coli and other Gram-negative bacteria [30].

Amyloid fibres are found in most natural biofilms [36-39]. Although differing in the sequences of their protein subunits, amyloid fibres exhibit similar molecular superstructures classically consisting of cross-beta sheets that further assemble into fibrils and finally fibres [39]. These are insoluble in sodium dodecyl sulfate (SDS), proteinase K resistant and typically stain with Congo red (CR) and thioflavin T/S. Recent data indicate a certain structural variability that also includes cross-beta helical structures in some of these fibres, with cross-beta sheet conformations being promoted by low $\mathrm{pH}$. Seeds of these structures are able to template additional subunits into amyloid fibres (recently summarized in [39]). From the perspective of bacteria, these fibres are 'functional' amyloids as they contribute to aggregation and protective properties of biofilms [39] and can also serve the bacteria as virulence factors in a host environment [40]. This is in contrast to the toxic amyloid fibres and plaques associated with neurodegenerative disorders such as Alzheimer's disease [41,42].

The best-studied biofilm-associated amyloids are curli fibres in E. coli and Salmonella enterica, which also occur in other enterics [41,43,44]. In E. coli, curli fibres are co-regulated with pEtN-cellulose $[45,46]$, with the two fibres tightly associating into a composite material and forming a large-scale matrix architecture within biofilms [24,29]. In many E. coli strains, curli fibres and cellulose are produced 
below $30^{\circ} \mathrm{C}$ only, suggesting a major role in environmental biofilms. However, curli fibres and/or pEtN-cellulose can also be produced at $37^{\circ} \mathrm{C}$ by certain commensal or pathogenic E. coli $[47,48]$. In the human intestine, curli fibres promote inflammation and can even trigger autoimmunity; i.e., also acting as a virulence factor [40,49-51]. Various Pseudomonas species produce Fap fibres (for functional amyloids in Pseudomonas) that have properties similar to curli fibres in enteric bacteria and that contribute to cellular aggregation in biofilms as well as to the virulence of pathogenic pseudomonads [52]. Also, Gram-positive bacteria use functional amyloids or amyloid-like fibres as biofilm matrix components. These include TasA fibres made by Bacillus subtilis which feature both alpha-helical and cross-beta sheet regions, with the fraction of the latter increasing at acidic $\mathrm{pH}[53,54]$. Staphylococci generate various extracellular matrix-localized fibres from phenol-soluble modulins and other proteins, although these fibres do not seem to have all the properties of classical amyloids [39,40]. Finally, Streptococcus mutans, which plays an important role in the formation of dental plaque and the oral dysbiosis leading to caries [55], does not only produce exopolysaccharides it its biofilms, but also several exoproteins that can form amyloid fibres (summarized in [39]).

As bacterial biofilms are highly diverse in their structure and matrix composition, several model systems are currently used in research addressing both the formation and the inhibition of biofilms [29,56]: (i) submerged biofilms that form on the walls of microtiter dishes in which the biofilms' overall mass can be easily quantified by staining with crystal violet or other dyes, (ii) macrocolonies growing for extended times at a semi-solid surface (agar)/air interface that are highly amenable to genetic approaches, and (iii) pellicles forming at static fluid/air interfaces [56]. In searching for and characterizing anti-biofilm agents, submerged biofilm models have been widely used, which due to the low cost and simplicity of the procedure can also be adapted to high-throughput screening. The more structured, CR-stainable and genetically analyzable macrocolonies as well as pellicles have become important more recently, especially in attempts to clarify the molecular mechanisms of actions of anti-biofilm agents.

\section{EGCG Can Interfere with Bacterial Biofilm Formation}

Green tea and its major constituent polyphenol EGCG, as well as many other plant-produced polyphenols, have long been discussed as being beneficial for human health. which is usually attributed to their general anti-oxidant and anti-inflammatory properties [19,57]. EGCG was also among one of the first polyphenols to have its effects tested on bacteria. While relatively high concentrations of EGCG were found to be toxic for various bacterial species (summarized by $[58,59]$ ), sub-inhibitory concentrations indeed often show anti-biofilm activity. Thus, a mixture of green tea catechins, most notably EGCG, was observed to reduce the adherence of $S$. mutans to surfaces, to somehow interfere with bacterial glucosyltransferases involved in biofilm formation and to be anti-cariogenic in animals and humans (summarized by $[60,61])$. EGCG was found to reduce submerged biofilm formation in microtiter dishes as well as swarming of Burkholderia cepacia [62]. Similar results for submerged biofilm formation were also obtained with Staphylococci [63], in particular with a series of ocular isolates of $S$. aureus and S. epidermidis. Here, EGCG also reduced CR staining of colonies, and scanning electron microscopy revealed strongly reduced matrix ('slime') production when Staphylococci were grown on corneal epithelial cells in vitro [64]. Since then, submerged biofilm formation under laboratory conditions was demonstrated to be impaired by EGCG for many more bacteria and in particular pathogenic species, including enterohemorrhagic E. coli (EHEC) [65]; P. aeruginosa [66]; Porphyromonas gingivalis (a member of the oral microbiota) [67,68]; Stenotrophomonas maltophilia isolated from the lung of a CF patient (here, biofilm formation was also reduced by EGCG in a mouse model) [69]; Enterococcus faecalis [70]; Campylobacter jejuni [71]; Shewanella baltica [72]; Streptococcus pneumoniae [73]; again, S. mutans (where EGCG effects on dental biofilms were also tested in vivo; i.e., in dogs); [74] and Fusobacterium nucleatum, another oral bacterium associated with periodontitis [75]. 


\section{Mechanisms of Action of EGCG on Bacterial Biofilms}

In general, the early reports on EGCG's effects were based on simply comparing the mass of bacteria adhered to microtiter dishes in the presence and absence of EGCG and remained mostly descriptive with respect to how the compound affected these biofilms. However, a few of the early as well as the more recent studies have begun to address the question of the potential mechanisms of action of EGCG. In some bacteria, such as P. aeruginosa, where biofilm formation involves intercellular communication by quorum sensing, EGCG can somehow disturb signaling via autoinducer-1/LuxR-dependent or autoinducer-2-dependent quorum sensing systems [62,66,72]. In several bacterial species, EGCG can also attenuate the expression or activity of specific virulence factors, as observed for instance for Shiga toxin in enterohemorrhagic E. coli (EHEC) [65,76] or staphylococcal enterotoxin B [77]. In $P$. gingivalis, EGCG down-regulates flagella as well as factors involved in tissue destruction and heme acquisition [68]. In E. faecalis, the EGCG-mediated down-regulation of certain virulence genes was shown to involve the formation of hydroxyl radicals [70]. In S. pneumoniae, EGCG seems to target specifically the virulence factors pneumolysin and sortase A [73]. Evidence of EGCG-mediated membrane damage, iron chelation and reduced synthesis of hemolysin and hydrogensulfide was reported for F. nucleatum [75]. Not all of these activities are necessarily direct, although the diversity of effects suggests that EGCG may target a variety of cellular factors. It is also not clear which of these effects are related to the anti-biofilm action of EGCG, although virulence and biofilm genes are often co-regulated in complex manners. An exception is S. mutans, where the anti-biofilm effect of EGCG seems related to its ability to reduce the expression of the three genes $(g t f B, g t f C, g t f D)$ that encode the glycosyltransferases that synthesize the biofilm-associated exopolysaccharides [78,79]. Although a number of target processes have thus been identified, the molecular mechanisms by which EGCG directly interferes with these remained mostly elusive in these studies.

In recent searches for molecular mechanisms targeted by EGCG, which are specifically related to biofilms, several strategies have been followed and combined: (i) theoretical considerations based on known molecular mechanisms of biofilm formation and control $[12,80]$ to pinpoint appropriate targets for inhibition; (ii) the use of plate-grown macrocolony biofilms as an experimental biofilm system that-in contrast to microtiter dish-grown biofilms-allows to genetically characterize targets and mechanisms of action [23,24,81]; and (iii) taking into account reports on how EGCG acts in other systems, in particular in human biochemistry and physiology (see below), to get hints on direct molecular mechanisms of action that may also occur in bacteria.

Appropriate targets for the inhibition of biofilm formation should be components or processes that are crucial for the essential properties of most bacterial biofilms. While quorum sensing (QS) is not as generally involved in biofilm control as initially assumed, and the biochemical nature of QS signaling molecules is diverse, two other biochemical processes are widely conserved in biofilms: the formation of amyloid fibres in many biofilm matrices [36] and the regulation by the second messenger bis- $\left(3^{\prime}, 5^{\prime}\right)$-cyclic diguanosine monophosphate (c-di-GMP), which rather ubiquitously activates exopolysaccharide synthases and/or the expression of numerous genes involved in bacterial biofilm formation [35,82-85]. Targeting a matrix component or process such as amyloidogenesis would have the additional advantage that an inhibitory molecule could act from outside; i.e., it would not have to traverse the entire cell envelope. This would be necessary to target for instance the cytoplasmic c-di-GMP-synthesizing diguanylate cyclases, which all share the same catalytic mechanism in their GGDEF domains (with this name standing for the highly conserved amino acids that define the active centre) [86]. With respect to activities in a human biochemical context, EGCG was shown to prevent amyloid formation in vitro by the A-beta and alpha-synuclein peptides, which are associated with Alzheimer's and Parkinson's diseases, respectively, by inducing the formation of non-toxic off-pathway oligomers [87-89]. Furthermore, EGCG inhibits amyloid fibre formation and even disrupts preformed fibres of a mutant version of transthyretin which is associated with familial amyloidotic polyneuropathy, where these extracellular fibres accumulate in connective tissue [90]. 
Since these considerations suggested biofilm amyloid formation as a prime candidate for being targeted by EGCG, the action of the compound was tested with macrocolony biofilms of commensal and pathogenic E. coli strains [80], where the wrinkled morphotype depends on the high production of amyloid curli fibres and pEtN-cellulose [24,29]. EGCG was indeed found to essentially eliminate the entire CR-stainable extracellular matrix; i.e., curli fibres as well as pEtN-cellulose (Figure 1). This drastic EGCG effect is due to a combination of (i) an anti-amyloidogenic activity, which results in curli subunits (or oligomers) remaining soluble in sodium dodecyl sulfate (SDS) and diffusing into the agar-containing medium below the biofilm, and (ii) triggering the cell surface stress response pathway governed by the alternative sigma factor RpoE $\left(\sigma^{\mathrm{E}}\right.$; summarized in Figure 2$)$. RpoE induces the small regulatory RNA RybB, which directly binds to and interferes with the translation of the mRNA for the biofilm regulator $\mathrm{CsgD}$, which in turn is required to transcribe the curli genes as well as the gene for a diguanylate cyclase that is essential to specifically activate cellulose synthase [80]. How exactly EGCG triggers the RpoE-mediated cell envelope stress response is not yet clear; in part, because the signal input generally is the least understood part of this stress response. However, EGCG was observed to interact with lipid bilayers in cell membranes [91,92] and to induce small perforations and grooves in the cell surface of EHEC; i.e., to clearly induce cell envelope damage [93].

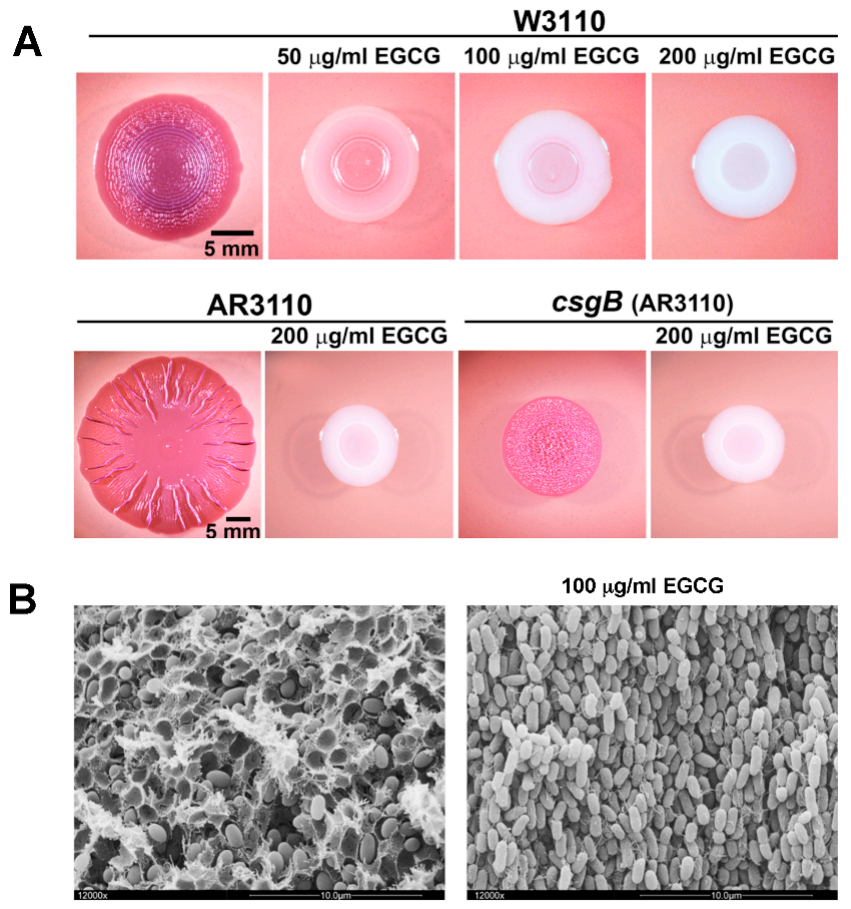

Figure 1. Epigallocatechin-3-gallate (EGCG) prevents the formation of amyloid curli fibres and pEtN-cellulose; i.e., the two major components of the extracellular matrix of macrocolony biofilms of E. coli. (A) Macrocolony biofilms of the standard E. coli K-12 strain W3110 (which produces only curli fibres), its derivative strain AR3110 (which produces curli fibres and pEtN-cellulose) and the $\operatorname{csg} B$ mutant derivative of strain AR3110 (which produces only pEtN-cellulose) were grown on salt-free complex medium agar plates for five days at $28^{\circ} \mathrm{C}$. Plates were supplemented with Congo red (which binds to and stains curli fibres as well as pEtN-cellulose fibrils) and the indicated concentrations of EGCG, which results in a white colour indicating an absence of the polymeric matrix components. Note that colony wrinkling patterns show characteristic differences depending on whether the matrix consists of the curli/pEtN-cellulose composite or of either component alone. (B) High-resolution scanning electron micrographs show tight surrounding of $E$. coli cells by the composite curli/pEtN-cellulose matrix inside a macrocolony biofilm of strain AR3100 (left panel), whereas no matrix is present with EGCG during growth (right panel). The few filamentous structures visible in the right panel are flagella, which are unaffected by EGCG. The photographs shown here were previously published [80] under the Creative Commons Attribution- NonCommercial-NoDerivatives license (CC-NC-ND); ${ }^{\complement}$ the author. 
Besides showing anti-amyloidogenic activity of EGCG in a bacterial biofilm model, this study [80] thus also revealed a novel target for biofilm interference-cell envelope stress responses, which in multiple and complex manners respond to protein folding and assembly stress at the bacterial surface and/or cell envelope. Under such stress conditions, these responses generally tune down the additional synthesis of proteins destined for the cell envelope [94-97]. This includes proteins involved in large molecular 'construction sites' such as the trans-cell envelope machineries for the controlled synthesis of amyloid fibres and exopolysaccharides [80]. If this applies also to the subunits of conjugative pili, it may explain the observation that EGCG can reduce conjugative R plasmid transfer [98]. Without even having to enter bacterial cells, EGCG thus highly efficiently interferes with the macrocolony biofilm formation of $E$. coli by synergistically targeting two crucial processes.

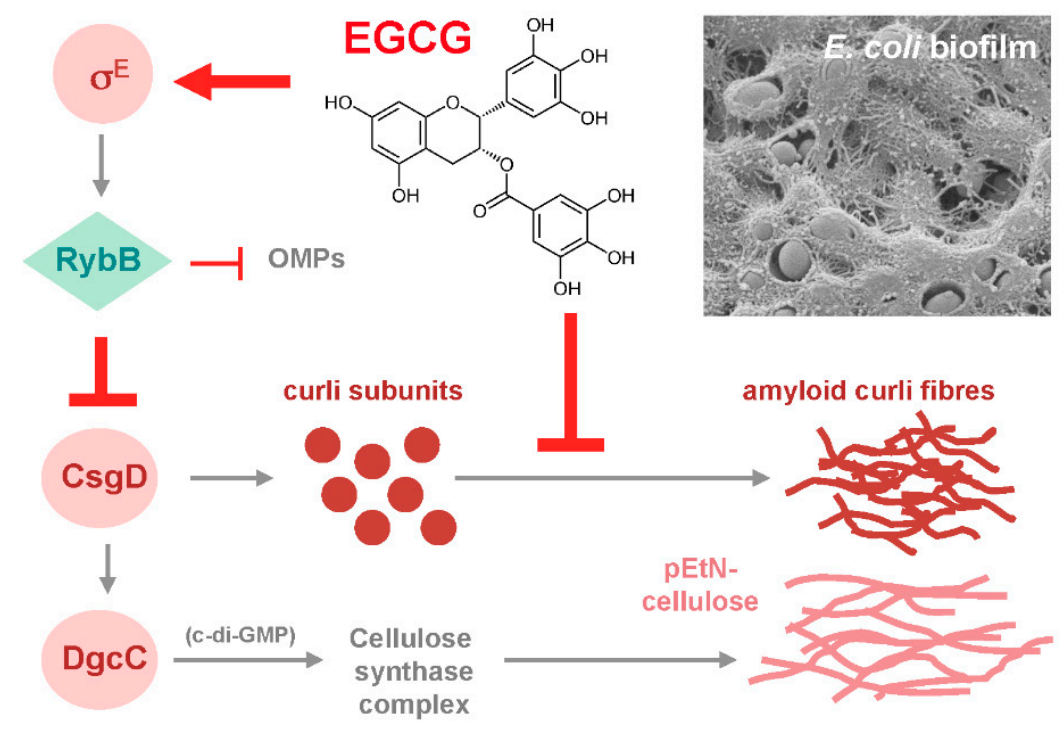

Figure 2. Summary of the mechanisms of action of EGCG on E. coli macrocolony biofilms. EGCG interferes with the production of both amyloid curli fibres and $\mathrm{pEtN}$-cellulose fibril—which together form the fibrous matrix material visible in the scanning electron micrograph of the surface of an $E$. coli macrocolony biofilm shown in the upper right corner-by two separate but synergistically acting processes: (i) EGCG directly interferes with the formation of amyloid fibres from curli subunits; and (ii) EGCG induces the $\sigma^{\mathrm{E}}$ (RpoE)-mediated cell envelope stress response, which drives increased synthesis of the small regulatory RNA RybB, which in turn reduces the expression of CsgD as well as of many outer membrane proteins (OMPs). The biofilm regulator $\mathrm{CsgD}$ is required for the expression of the curli subunits as well as of $\mathrm{DgcC}$, the diguanylate cyclase that produces the second messenger c-di-GMP required to activate cellulose synthase as well as the associated phosphoethanolamin (pEtN) modification system. The figure was previously published [80] under the CC-NC-ND license; (c) the author.

In parallel, two studies with other bacterial amyloids also found these to be directly targeted by EGCG. This applies to Fap fibres in certain types of P. aeruginosa biofilms, where the major subunit FapC is remodeled into oligomers by EGCG, resulting in less stiff biofilms [99]. Since Fap fibres play an important role in P. aeruginosa biofilms in the infected CF lung, a nebulized administration of EGCG to CF patients was proposed as a potential treatment option which is worth further study [99]. The fap genes occur in various branches of proteobacteria, including a number of pathogens, and besides rendering biofilms highly aggregative and adherent, Fap fibres also seem to act as virulence factors [40]. Accordingly, the fap operon was highly activated in acute burn and chronical surgical wound infections of $P$. aeruginosa in a mouse model [100]. Another line of evidence shows that EGCG prevents fibril formation from the phenol-soluble modulins (PSM) of Staphylococcus species and can even disaggregate preformed fibrils [101]. PSMs have been shown to contribute to virulence in various ways, although it is still under debate whether these toxic activities require the fibrous forms of PSMs [40]. Given that 
P. aeruginosa and S. aureus are major biofilm-forming pathogens in chronic wound infection [102-104], the interference of EGCG with the biofilm-associated amyloid or amyloid-like fibres of these two pathogens and a putative therapeutic use of EGCG in this context certainly deserve further study.

\section{Can EGCG Act Synergistically with Antibiotics on Bacterial Biofilms?}

The high antibiotic tolerance of bacteria residing in biofilms severely impedes the antibiotic treatment of many chronic infections $[5,6,8,105,106]$. Therefore, drugs that can prevent biofilm formation are believed to also reduce biofilm-associated antibiotic tolerance, thereby allowing antibiotics to act more efficiently on biofilm-associated infections $[11,12,17]$. However, biofilm-related antibiotic tolerance is multifactorial, just as biofilm formation as a whole, is complex and involves many different molecular processes [107]. Certain extracellular matrix components can restrict diffusion and trap distinct antibiotics; i.e., the matrix can act as an effective filter that protects bacterial cells inside a biofilm against antibiotic exposure [108-110]. The viscoelastic behavior of submerged biofilms also affects water channels and thereby can influence rates of antibiotic penetration [111]. Moreover, most cells in a densely populated biofilm are in a physiological state of stationary phase, which renders cells not only tolerant against antibiotics that target the growing cell wall, but also induces pronounced multiple stress resistance which may involve changes in certain antibiotic target structures and processes [56,112-114]. Furthermore, distinct antibiotic efflux pumps were found to be specifically induced in biofilm-dwelling bacteria [115,116]. Finally, the formation of persister cells, which are in a non-growing and/or dormant state, contribute to antibiotic tolerance in biofilms [117].

Because of this complexity, a given anti-biofilm agent is unlikely to counteract antibiotic tolerance in general, just as it is unlikely to target all processes involved in biofilm formation; after all, it is now clear that biofilm formation is not a process governed by a single hierarchically organized developmental pathway [56,118-120]. As a consequence, a specific anti-biofilm agent such as EGCG may contribute to suppress tolerance against a specific antibiotic in biofilms of a specific bacterial species, but 'magic bullet' synergistic activities with various antibiotics against biofilms in general are not to be expected. On the other hand, distinct activities of EGCG, which affect different molecular targets in bacterial cells, may combine to counteract both the more classical antibiotic resistance as well as biofilm-associated antibiotic tolerance. Notably, the underlying molecular mechanisms (e.g., efflux pumps) are often principally similar, no matter whether these are acquired via mobile genetic elements or are part of the 'normal' physiological repertoire activated in biofilms as described above.

Nevertheless, synergy between EGCG and certain antibiotics has been found in a series of studies, although earlier studies in particular did not focus on counteracting biofilm-associated antibiotic tolerance specifically. Thus, synergy of EGCG with $\beta$-lactams was found with methicillin-resistant S. aureus (MRSA) [121-123]. By binding to peptidoglycan, EGCG restored antimicrobial activity of penicillin against a penicillinase-producing S. aureus [124]. Besides reducing biofilm formation by P. gingivalis, EGCG affected the growth of this oral bacterium synergistically with metronidazole [68]. EGCG also seems to interfere with the activities of certain antibiotic efflux pumps, as was shown for tetracycline efflux in Staphylococci [63] and ciprofloxacin efflux in $\beta$-lactamase-producing Klebsiella pneumoniae [125]. A biofilm-specific synergy was reported for P. aeruginosa, where EGCG remodels not only Fap fibres in the biofilm matrix as described above, but also increases the susceptibility of the biofilm to tobramycin [99].

On the other hand, specific anti-biofilm activity of EGCG and a reduction in biofilm-associated antibiotic tolerance are not necessarily coupled. Under certain conditions, EGCG was found to even promote biofilm formation and to increase tobramycin resistance of P. aeruginosa [126]. The underlying molecular mechanisms have not been clarified but it is conceivable that by reducing amyloid fibre formation, EGCG may lead to better exposure of some biofilm-promoting adhesin(s) on the bacterial surface. Similarly, exposure to EGCG reduced susceptibility to several antibiotics in S. aureus [127].

Overall, more studies of potential synergies between EGCG and distinct antibiotics specifically in biofilms of relevant pathogenic bacterial species are required while keeping in mind that even 
opposite and thus counterproductive effects can occur. Studies of synergies could be guided by the increasing knowledge about the direct molecular targets of EGCG. For instance, the finding that EGCG strongly reduces the formation of amyloid fibres and pEtN-cellulose fibrils $[80,99,101]$ suggests putative synergy specifically with antibiotics that are tolerated by biofilms due to their binding by these matrix components.

\section{Why do Plants Produce Antibiofilm Agents such as EGCG?}

There is a huge body of literature on the therapeutic use of EGCG for various human diseases, including neurodegenerative diseases, cancer and infectious diseases [59,128-130]. However, EGCG-producing plants have neither evolved nor been bred to help humans treat diseases. So, why do plants produce catechins and epicatechins in sometimes strikingly high concentrations, as is the case for EGCG in Camellia sinensis [131]? Polyphenols in general are anti-oxidants and can protect the producing plants, for example, against UV irradiation [132]). They have also been implicated in resistance against bacterial or fungal plant pathogens [133-135], which is consistent with effects on the expression of certain virulence genes as mentioned above.

As shown by recent studies [80,99,101], EGCG exhibits strong anti-amyloidogenic function at much lower concentrations than antimicrobial effects (with E. coli, for instance, the formation of amyloid curli fibres is inhibited at $<50 \mu \mathrm{g} / \mathrm{mL}$, whereas the minimal inhibitory concentration or MIC is $>10$-fold higher) - a property indicating that EGCG is a potent anti-biofilm agent against bacterial biofilms that contain amyloid fibres as a major extracellular matrix component. The same applies to pEtN-cellulose fibrils, the production of which is equally inhibited by EGCG [80] and which are also common in bacterial biofilm matrices [30]. The general question why plants produce EGCG can thus be rephrased more specifically: do plants come into contact with bacterial biofilms containing amyloid fibres or $\mathrm{pEtN}$-cellulose to the point that they have to antagonize their deposition or formation on their surfaces?

The life cycle of enteric bacteria such as E. coli or Salmonella, which occur in mammals, birds and other animals, includes shedding into the environment [136]. Due to their general and specific stress responses, these bacteria are well equipped to survive or even grow in very different and stressful environments outside their hosts [137]. This includes bacterial life on the leaves of plants, i.e., in the phyllosphere, where bacteria are exposed to nutrient limitation, desiccation and large changes in temperature and UV irradiation [138,139]. Notably, from the bacterial perspective, firmly attaching to plant leaves seems an attractive strategy to find a way back into the intestines of plant-eating mammalian hosts. In fact, a number of reports have shown that curli fibres and pEtN-cellulose are induced and involved in the formation of enteric biofilms on plant surfaces, both in the phyllosphere and the rhizosphere [140-145].

On the other hand, plants-as with all macroorganisms-have to generally control bacterial growth on their surfaces and, in particular, have to defend themselves against being colonized by phytopathogenic bacteria. To achieve this, plants have evolved both constitutive and inducible defense mechanisms based on the use of chemicals. While constitutive defense strategies include the production of essential oils and various other secondary metabolites, inducible defense uses specific recognition events that trigger molecular responses that lead to the production of reactive oxygen species, toxic phytoalexins and signaling compounds such as salicylic acid, jasmonic acid and ethylene [146-149]. Antimicrobial action as well as specific effects of these compounds on virulence mechanisms have been described in many studies [18,150]. However, instead of completely clearing bacteria and thereby opening new niches for potentially worse pathogens, the plant phylosphere and rhizosphere are associated with a complex microbiota $[138,151]$. Thus, plants actively promote the growth of beneficial bacteria [152] and interfere with the growth of specific pathogens; e.g., by targeting the latter's specific virulence mechanisms [18].

Chemical communication implies that plants have to maintain their microbiota in an accessible and manageable state; i.e., plants should 'domesticate' their microflora by inhibiting or at least controlling 
bacterial biofilm formation. Hence, plants can be expected to have evolved an arsenal of effective anti-biofilm compounds. Seen from the plant perspective, producing high levels of EGCG most likely is a strategy to interfere with the formation of amyloid and/or pEtN-cellulose-containing bacterial biofilms on their surfaces. Directly targeting these extracellular matrix components also seems an attractive strategy because, with this mode of action, anti-biofilm agents do not have to penetrate bacterial cell envelopes, in contrast to compounds that would directly affect intracellular anti-biofilm targets such as c-di-GMP-synthesizing diguanylate cyclases. Similarly, signaling pathways that respond to cell envelope stress can be triggered from outside, which allows indirect manipulation of bacterial gene expression or intracellular signaling. Notably, EGCG—like many polyphenols, a water-soluble compound-acts from outside both on biofilm matrix fibre assembly and on a cell envelope stress response that down-regulates the biosynthesis of the matrix fibre building blocks (summarized in Figure 2). Finally, based on these general considerations as well as the specific findings for EGCG, we may expect additional plant secondary compounds to show anti-biofilm activity-a hypothesis that could direct future experimental studies.

\section{Conclusions and Perspectives}

As a compound with anti-amyloidogenic properties and the ability to interfere with the production of bacterial pEtN-cellulose fibrils, EGCG is a potent inhibitor of the formation of certain types of biofilms, namely those that use amyloid fibres and $\mathrm{pEtN}$-cellulose as major extracellular matrix components. As described above, this has been studied in most detail with E. coli [80], but seems to apply for instance also to bacteria in oral biofilms [153]. Accordingly, EGCG alone or added to materials used in dentistry has yielded promising results with respect to reducing the growth and/or surface adhesion of $S$. mutans and caries formation $[60,78,154-158]$. Furthermore, EGCG is effective against the formation of amyloids or amyloid-like fibres in biofilms of P. aeruginosa and S. aureus [99,101]. The anti-biofilm activity of EGCG against these two bacterial species, which are commonly found in chronic wound infections, may thus add to other wound-healing effects of EGCG [159-162]. Topical applications against oral or wound biofilms would also be less affected by the limited stability and bioavailability of EGCG due to oxidation and degradation by the intestinal microbiota [163-166].

However, EGCG neither seems a general anti-biofilm agent nor do its specific anti-biofilm properties necessarily lead to a reduction in biofilm-associated antibiotic tolerance. Under certain conditions, EGCG was found to even promote biofilm formation and/or to increase tolerance of certain antibiotics $[126,127]$. Certain cell envelope stress signaling pathways triggered by EGCG could lead to a stress-protective response that actually promotes biofilm formation and the associated antibiotic tolerance. Given the complexities of bacterial physiological reactions, beneficial effects of EGCG against biofilms thus seem quite specific and conditional, with counterproductive effects not being excluded.

Amyloid curli fibres of enteric bacteria are not only important biofilm matrix components but can also elicit pro-inflammatory effects in human hosts [51]. The temperature regulation of curli is relaxed in many commensal or pathogenic intestinal E. coli; i.e., these strains express curli also at human body temperature $[47,48]$. Antibodies against CsgA, the major curli subunit, have been detected in serum from sepsis patients but not in healthy controls, and curli was shown to induce a variety of proinflammatory cytokines [167], with curli being recognized by Toll-like receptors 1 and $2[49,168,169]$. Curli-DNA composites which can form in biofilm matrices can also stimulate the auto-immune response underlying systemic lupus erythematosus [50]. Taken together, this suggests a detrimental role of amyloid fibres produced by members of the human gut microbiota, which may be relevant in the chronically inflamed intestine. Inflammatory bowel diseases are characterized by enteric blooms; i.e., a strong increase in the relative abundance of mostly E. coli. These bacteria benefit from and promote inflammation, thereby stabilizing the inflamed state [170]. That green tea polyphenols are beneficial in the treatment of inflammatory bowel disease has been attributed to their effects on various components of the host pro-inflammatory control network [170-173]. However, also processes 
on the bacterial side, i.e., a putative involvement of pro-inflammatory curli fibres in chronic intestinal inflammation as well as the inhibition of curli production by EGCG, certainly deserve further study.

In general, a mutual interplay between EGCG and the gut microbiota seems to be currently emerging as a new intriguing field of study [167]. EGCG has a beneficial effect in cancer therapy [165,174], and specific microbiota-produced metabolites derived from EGC and EGCG were shown to interfere with the proliferation of cervical cancer (HeLa) cells [175]. Both EGCG and its microbiota-generated derivatives can scavenge toxic cellular reactive metabolites involved in the development of various chronic diseases [176]. EGCG was also found to prevent or even counteract high-fat diet-induced changes in the gut microbiota [177-179]. The specific processes underlying these beneficial effects of EGCG are not fully understood, but it is already apparent that they are multifactorial. Direct anti-oxidative effects by scavenging toxic reactive metabolites and the prevention of inflammation-both by targeting specific components of the innate immune system and by inhibiting the production of pro-inflammatory bacterial amyloids-are likely to operate synergistically in the molecular mechanism of action of EGCG.

Humans have used plant-derived materials for medical purposes for a long time without knowing or even asking how and why these agents were effective. Molecular biology is now unraveling the molecular mechanisms of action. In addition, the ecophysiological relationships between plants, bacteria, animals and humans now reveal why plants have evolved anti-amyloidogenic compounds such as EGCG. These compounds do not only prevent the formation of biofilms on plant surfaces, but at the same time can combat biofilms in chronic infections and even seem of value against toxic amyloid-associated neuropathological diseases.

Funding: Research in the author's laboratory mentioned in this review has been funded by Deutsche Forschungsgemeinschaft [DFG; grant numbers He1556/17-1, 20-1 and 21-1] and Berliner Sparkassenstiftung Medizin. Publication support by the DFG and the Open Access Publication Fund of Humboldt-Universität zu Berlin is also gratefully acknowledged.

Acknowledgments: The author would like to thank Diego O. Serra and Mihaela Pruteanu for carefully reading and commenting on the manuscript.

Conflicts of Interest: The author declares no conflict of interest. The funding sponsors had no role in the design of the study; in the collection, analyses, or interpretation of data; in the writing of the manuscript, and in the decision to publish the results.

\section{References}

1. Stoodley, P.; Sauer, K.; Davies, D.G.; Costerton, J.W. Biofilms as complex differentiated communities. Annu. Rev. Microbiol. 2002, 56, 187-209. [CrossRef] [PubMed]

2. Hall-Stoodley, L.; Costerton, J.W.; Stoodley, P. Bacterial biofilms: From the natural environment to infectious diseases. Nat. Rev. Microbiol. 2004, 2, 95-108. [CrossRef] [PubMed]

3. Flemming, H.-C.; Wingender, J.; Szewzyk, U.; Steinberg, P.; Rice, S.A.; Kjelleberg, S. Biofilms: An emergent form of bacterial life. Nat. Rev. Microbiol. 2016, 14, 563-575. [CrossRef] [PubMed]

4. Flemming, H.-C.; Wuertz, S. Bacteria and archaea on Earth and their abundance in biofilms. Nat. Rev. Microbiol. 2019, 17, 247-260. [CrossRef] [PubMed]

5. Anderson, G.G.; O’Toole, G.A. Innate and induced resistance mechanisms of bacterial biofilms. Curr. Top. Microbiol. Immunol. 2008, 322, 87-107.

6. Arciola, C.R.; Campoccia, D.; Montanaro, L. Implant infections: Adhesion, biofilm formation and immune evasion. Nat. Rev. Microbiol. 2018, 16, 397-409. [CrossRef] [PubMed]

7. Costerton, J.W.; Stewart, P.S.; Greenberg, E.P. Bacterial biofilms: A common cause of persistent infections. Science 1999, 284, 1318-1322. [CrossRef] [PubMed]

8. Römling, U.; Kjelleberg, S.; Normark, S.; Nyman, L.; Uhlin, B.E.; Åkerlund, B. Microbial biofilm formation: A need to act. J. Intern. Med. 2014, 276, 98-110. [CrossRef] [PubMed]

9. Richards, J.J.; Melander, C. Controlling bacterial biofilms. Chembiochem 2009, 10, 2287-2294. [CrossRef] [PubMed] 
10. Stewart, P.S. Prospects for anti-biofilm pharmaceuticals. Pharmaceuticals 2015, 8, 504-511. [CrossRef] [PubMed]

11. Rabin, N.; Zheng, Y.; Opoku-Tememg, C.; Du, Y.; Bonsu, E.; Sintim, H.O. Agents that inhibit bacterial biofilm formation. Future Med. Chem. 2015, 7, 647-671. [CrossRef] [PubMed]

12. Sintim, H.O.; Smith, J.A.; Wang, J.; Nakayama, S.; Yan, L. Pradigm shift in discovering next-generation anti-infective agents: Targeting quorum sensing, c-di-GMP signaling and biofilm formation in bacteria with small molecules. Future Med. Chem. 2010, 2, 1005-1035. [CrossRef] [PubMed]

13. Yang, L.; Givskov, M. Chemical biology strategies for biofilm control. Microbiol. Spectr. 2015, 3. [CrossRef] [PubMed]

14. Peach, K.C.; Bray, W.M.; Shikuma, N.J.; Gassner, N.C.; Lokey, R.S.; Yildiz, F.H.; Linington, R.G. An image-based 384-well high-throughput screening method for the discovery of biofilm inhibitors in Vibrio cholerae. Mol. Biosyst. 2011, 7, 1176-1184. [CrossRef] [PubMed]

15. Budzynska, A.; Wieckowska-Szakiel, M.; Sadowska, B.; Kalemba, D.; Rozalska, B. Antibiofilm activity of selected plant essential oils and their major components. Polish. J. Microbiol. 2011, 60, 35-41.

16. Stowe, S.D.; Richards, J.J.; Tucker, A.T.; Thompson, R.; Melander, C.; Cavanagh, J. Anti-biofilm compounds derived from marine sponges. Mar. Drugs 2011, 9, 2010-2035. [CrossRef]

17. Khan, M.S.; Lee, J. Novel strategies for combating pathogenic biofilms using plant products and microbial antibiotics. Curr. Pharm. Biotechnol. 2015, 17, 126-140. [CrossRef]

18. Nunes Silva, L.; Zimmer, K.R.; Macedo, A.J.; Silva Trentin, D. Plant natural products targeting bacterial virulence factors. Chem. Rev. 2016, 116, 9162-9236. [CrossRef]

19. Mereles, D.; Hunstein, W. Epigallocatechin-3-gallate (EGCG) for clinical trials: More pitfalls than promises? Int. J. Mol. Sci. 2011, 12, 5592-5603. [CrossRef]

20. Branda, S.S.; Vik, A.; Friedman, L.; Kolter, R. Biofilms: The matrix revisited. Trends Microbiol. 2005, 13, 20-26. [CrossRef]

21. Flemming, H.-C.; Wingender, J. The biofilm matrix. Nat. Rev. Microbiol. 2010, 8, 623-633. [CrossRef] [PubMed]

22. Römling, U. Characterization of the rdar morphotype, a multicellular behaviour in Enterobacteriaceae. Cell. Mol. Life Sci. 2005, 62, 1234-1246. [CrossRef] [PubMed]

23. Serra, D.O.; Richter, A.M.; Klauck, G.; Mika, F.; Hengge, R. Microanatomy at cellular resolution and spatial order of physiological differentiation in a bacterial biofilm. MBio 2013, 4, e00103-13. [CrossRef] [PubMed]

24. Serra, D.O.; Richter, A.M.; Hengge, R. Cellulose as an architectural element in spatially structured Escherichia coli biofilms. J. Bacteriol. 2013, 195, 5540-5554. [CrossRef] [PubMed]

25. Okegbe, C.; Price-Whelan, A.; Dietrich, L.E. Redox-driven regulation of microbial community morphogenesis. Curr. Opin. Microbiol. 2014, 18, 39-45. [CrossRef]

26. Vidakovic, L.; Singh, P.K.; Hartmann, R.; Nadell, C.D.; Drescher, K. Dynamic biofilm architecture confers individual and collective mechanisms of viral protection. Nat. Microbiol. 2018, 3, 26-31. [CrossRef]

27. Zogaj, X.; Nimtz, M.; Rohde, M.; Bokranz, W.; Römling, U. The multicellular morphotypes of Salmonella typhimurium and Escherichia coli produce cellulose as the second component of the extracellular matrix. Mol. Microbiol. 2001, 39, 1452-1463. [CrossRef]

28. Römling, U.; Galperin, M.Y. Bacterial cellulose biosynthesis: Diversity of operons, subunits, products, and functions. Trends Microbiol. 2015, 23, 545-557. [CrossRef]

29. Serra, D.O.; Hengge, R. Cellulose in bacterial biofilms. In Extracellular Sugar-Based Biopolymer Matrices; Cohen, E., Merzendorfer, H., Eds.; Springer International Publishing: Basel, Switzerland, 2019.

30. Thongsomboon, W.; Serra, D.O.; Possling, A.; Hadjineophytou, C.; Hengge, R.; Cegelski, L. Phosphoethanolamine cellulose: A naturally produced chemically modified cellulose. Science 2018, 359, 334-338. [CrossRef]

31. Friedman, L.; Kolter, R. Two genetic loci produce distinct carbohydrate-rich structural components of the Pseudomonas aeruginosa biofilm matrix. J. Bacteriol. 2004, 186, 4457-4465. [CrossRef]

32. Yildiz, F.H.; Schoolnick, G.K. Vibrio cholerae O1 El Tor: Identification of a gene cluster required for the rugose colony type, exopolysaccharide production, chlorine resistance, and biofilm formation. Proc. Natl. Acad. Sci. USA 1999, 96, 4028-4033. [CrossRef]

33. Sutherland, I.W. Structural studies on colanic acid, the common exopolysaccharide found in the Enterobacteriaceae, by partial acid hydrolysis. Biochem. J. 1970, 115, 935-945. [CrossRef] 
34. Mann, E.E.; Wozniak, C.E. Pseudomonas biofilm matrix composition and niche biology. FEMS Microbiol. Rev. 2012, 36, 893-916. [CrossRef] [PubMed]

35. Whitney, J.C.; Howell, P.L. Synthase-dependent exopolysaccharide secretion in Gram-negative bacteria. Trends Microbiol. 2013, 21, 63-72. [CrossRef] [PubMed]

36. Larsen, P.; Nielsen, J.L.; Dueholm, M.S.; Wetzel, R.; Otzen, D.; Nielsen, P.H. Amyloid adhesins are abundant in natural biofilms. Environ. Microbiol. 2007, 9, 3077-3090. [CrossRef] [PubMed]

37. Blanco, L.P.; Evans, M.L.; Smith, D.R.; Badtke, M.P.; Chapman, M.R. Diversity, biogenesis and function of microbial amyloids. Trends Microbiol. 2012, 20, 66-73. [CrossRef] [PubMed]

38. Taglialegna, A.; Lasa, I.; Valle, J. Amyloid structures as biofilm matrix scaffolds. J. Bacteriol. 2016, 198, 2579-2588. [CrossRef] [PubMed]

39. Erskine, E.; MacPhee, C.E.; Stanley-Wall, N.R. Functional amyloid and other protein fibers in the biofilm matrix. J. Mol. Biol. 2018, 430, 3642-3656. [CrossRef]

40. Van Gerven, N.; Van der Verren, S.E.; Reiter, D.M.; Remaut, H. The role of functional amyloids in bacterial virulence. J. Mol. Biol. 2018, 430, 3657-3684. [CrossRef]

41. Evans, M.L.; Chapman, M. Curli biogenesis: Order out of disorder. Biochim. Biophys. Acta 2014, 1843, 1551-1558. [CrossRef]

42. Fändrich, M. Oligomeric intermediates in amyloid formation: Structure determination and mechanisms of toxicity. J. Mol. Biol. 2012, 421, 427-440. [CrossRef] [PubMed]

43. Dueholm, M.S.; Nielsen, S.B.; Hein, K.L.; Nissen, P.; Chapman, M.; Christiansen, G.; Nielsen, P.H.; Otzen, D.E. Fibrillation of the major curli subunit CsgA under a wide range of conditions implies a robust design of aggregation. Biochemistry 2011, 50, 8281-8290. [CrossRef] [PubMed]

44. Deshmukh, M.; Evans, M.L.; Chapman, M.R. Amyloid by design: Intrinsic regulation of microbial amyloid assembly. J. Mol. Biol. 2018, 430, 3631-3641. [CrossRef] [PubMed]

45. Römling, U.; Rohde, M.; Olsén, A.; Normark, S.; Reinköster, J. AgfD, the checkpoint of multicellular and aggregative behaviour in Salmonella typhimurium regulates at least two independent pathways. Mol. Microbiol. 2000, 36, 10-23. [CrossRef] [PubMed]

46. Brombacher, E.; Dorel, C.; Zehnder, A.J.B.; Landini, P. The curli biosynthesis regulator CsgD co-ordinates the expression of both positive and negative determinants for biofilm formation in Escherichia coli. Microbiology 2003, 149, 2847-2857. [CrossRef] [PubMed]

47. Bokranz, W.; Wang, X.; Tschape, H.; Römling, U. Expression of cellulose and curli fimbriae by Escherichia coli isolated from the gastrointestinal tract. J. Med. Microbiol. 2005, 54, 1171-1182. [CrossRef] [PubMed]

48. Richter, A.M.; Povolotsky, T.L.; Wieler, L.H.; Hengge, R. C-di-GMP signaling and biofilm-related properties of the Shiga toxin-producing German outbreak Escherichia coli O104:H4. EMBO Mol. Med. 2014, 6, 1622-1637. [CrossRef] [PubMed]

49. Tükel, C.; Nishimori, J.H.; Wilson, R.P.; Winter, M.G.; Keestra, A.M.; van Putten, J.P.; Bäumler, A.J. Toll-like receptors 1 and 2 cooperatively mediate immune responses to curli, a common amyloid from enterobacterial biofilms. Cell. Microbiol. 2010, 12, 1495-1505. [CrossRef] [PubMed]

50. Gallo, P.M.; Rapsinski, G.J.; Wilson, R.P.; Oppong, G.O.; Sriram, U.; Goulian, M.; Buttaro, B.; Caricchio, R.; Gallucci, S.; Tükel, C. Amyloid-DNA composites of bacterial biofilms stimulate autoimmunity. Immunity 2015, 42, 1171-1184. [CrossRef]

51. Spaulding, C.N.; Dodson, K.W.; Chapman, M.R.; Hultgren, S.J. Fueling the fire with fibres: Bacterial amyloids promote inflammatory disorders. Cell Host Microbe 2015, 18, 1-2. [CrossRef]

52. Rouse, S.L.; Matthews, S.J.; Dueholm, M.S. Ecology and biogenesis of functional amyloids in Pseudomonas. J. Mol. Biol. 2018, 430, 3685-3695. [CrossRef] [PubMed]

53. Romero, D.; Aguilar, C.; Losick, R.; Kolter, R. Amyloid fibres provide structural integrity to Bacillus subtilis biofilms. Proc. Natl. Acad. Sci. USA 2010, 107, 2230-2234. [CrossRef] [PubMed]

54. Diehl, A.; Roske, Y.; Ball, L.; Chowdhury, A.; Hiller, M.; Molière, N.; Kramer, R.; Stöppler, D.; Worth, C.L.; Schlegel, B.; et al. Structural changes of TasA in biofilms formation of Bacillus subtilis. Proc. Natl. Acad. Sci. USA 2018, 115, 3237-3242. [CrossRef] [PubMed]

55. Costalonga, M.; Herzberg, M.C. The oral microbiome and the immunobiology of periodontal disease and caries. Immunol. Lett. 2014, 162, 22-38. [CrossRef] [PubMed] 
56. Serra, D.O.; Hengge, R. Stress responses go three-dimensional-The spatial order of physiological differentiation in bacterial macrocolony biofilms. Environ. Microbiol. 2014, 16, 1455-1471. [CrossRef] [PubMed]

57. Bravo, L. Polyphenols: Chemistry, dietary sources, metabolism, and nutritional significance. Nutr. Rev. 1998, 56, 317-333. [CrossRef]

58. Steinmann, J.; Pietschmann, T.; Steinmann, E. Anti-infective properties of epigallocatechin-3-gallate (EGCG), a component of green tea. Br. J. Pharmacol. 2013, 168, 1059-1073. [CrossRef]

59. Reygaert, W.C. Green tea catechins: Their use in treating and preventing infectious diseases. BioMed Res. Int. 2018, 9105261. [CrossRef]

60. Hamilton-Miller, J.M.T. Anti-cariogenic properties of tea (Camellia sinensis). J. Med. Microbiol. 2001, 50, 299-302. [CrossRef]

61. Taylor, P.W.; Hamilton-Miller, J.M.T.; Stapleton, P.D. Antimicrobial properties of green tea catechins. Food Sci. Technol. Bull. 2005, 2, 71-81. [CrossRef]

62. Huber, B.; Eberl, L.; Feucht, W.; Polster, J. Influence of polyphenols on bacterial biofilm formation and quorum-sensing. Z. Naturforsch. 2003, 58, 879-884. [CrossRef]

63. Sudano Roccaro, A.; Blanco, A.R.; Giuliano, F.; Rusciano, D.; Enea, V. Epigallocatechin-gallate enhances the activity of tetracycline in staphylococci by inhibiting its efflux from bacterial cells. Antimicrob. Agents Chemother. 2004, 48, 1968-1973. [CrossRef] [PubMed]

64. Blanco, A.R.; Sudano-Roccaro, A.; Spoto, G.C.; Nostro, A.; Rusciano, D. Epigallocatechin gallate inhibits biofilm formation by ocular staphylococcal isolates. Antimicrob. Agents Chemother. 2005, 49, 4339-4343. [CrossRef] [PubMed]

65. Lee, K.M.; Kim, W.S.; Lim, J.; Nam, S.; Youn, M.; Nam, S.W.; Kim, Y.; Kim, S.H.; Park, W.; Park, S. Antipathogenic properties of green tea polyphenol epigallocatechin gallate at concentration below the MIC against enterohemorrhagic Escherichia coli O157:H7. J. Food Prot. 2009, 72, 325-331. [CrossRef] [PubMed]

66. Yang, L.; Liu, Y.; Sternberg, C.; Molin, S. Evaluation of enoyl-acyl carrier protein reductase inhibitors as Pseudomonas aeruginosa quorum-quenching reagents. Molecules 2010, 15, 780-792. [CrossRef]

67. Asahi, Y.; Noiri, Y.; Miura, J.; Maezono, H.; Yamaguchi, M.; Yamamoto, R.; Azakami, H.; Hayashi, M.; Ebisu, S. Effects of the tea catechin epigallocatechin gallate on Porphyromonas gingivalis biofilms. J. Appl. Microbiol. 2014, 116, 1164-1171. [CrossRef]

68. Fournier-Larente, J.; Morin, M.P.; Grenier, D. Green tea catechins potentiate the effect of antibiotics and modulate adherence and gene expression in Porphyromonas gingivalis. Arch. Oral Biol. 2016, 65, 35-43. [CrossRef]

69. Vidigal, P.G.; Müsken, M.; Becker, K.A.; Häussler, S.; Wingender, J.; Steinmann, E.; Kehrmann, J.; Gulbins, E.; Buer, J.; Rath, P.M.; et al. Effects of green tea compound epigallocatechin-3-gallate against Stenotrophomonas maltophilia infection and biofilm. PLoS ONE 2014, 9, e92876. [CrossRef]

70. Lee, P.; Tan, K.S. Effects of epigallocatechin gallate against Enterococcus faecalis biofilm and virulence. Arch. Oral Biol. 2015, 60, 393-399. [CrossRef]

71. Castillo, S.; Heredia, N.; García, S. 2(5H)-Furanone, epigallocatechin gallate, and a citric-based disinfectant disturb quorum-sensing activity and reduce motility and biofilm formation of Campylobacter jejuni. Folia Microbiol. 2015, 60, 89-95. [CrossRef]

72. Zhu, J.; Huang, X.; Zhang, F.; Feng, L.; Li, J. Inhibition of quorum sensing, biofilm, and spoilage potential in Shewanella baltica by green tea polyphenols. J. Microbiol. 2015, 53, 829-836. [CrossRef] [PubMed]

73. Song, M.; Teng, Z.; Li, M.; Niu, X.; Wang, J.; Deng, X. Epigallocatechin gallate inhibits Streptococcus pneumoniae virulence by simultaneously targeting pneumolysin and sortase A. J. Cell. Mol. Med. 2017, 21, 2586-2598. [CrossRef] [PubMed]

74. Bai, L.; Takagi, S.; Ando, T.; Yoneyama, H.; Ito, K.; Mizugai, H.; Isogai, E. Antimicrobial activity of tea catechin against canine oral bacteria and the functional mechanisms. J. Vet. Med. Sci. 2016, 78, 1439-1445. [CrossRef] [PubMed]

75. Ben Lagha, A.; Haas, B.J.; Grenier, D. Tea polyphenols inhibit the growth and virulence properties of Fusobacterium nucleatum. Sci. Rep. 2017, 7, 44815. [CrossRef] [PubMed]

76. Sugita-Konishi, Y.; Hara-Kudo, Y.; Amano, F.; Okubo, T.; Aoi, N.; Iwaki, M.; Kumagai, S. Epigallocatechin gallate and gallocatechin gallate in green tea catechins inhibit extracellular release of Vero toxin from enterohemorrhagic Escherichia coli O157:H7. Biochem. Biophys. Acta 1999, 1472, 42-50. [CrossRef] 
77. Hisano, M.; Yamaguchi, K.; Inoue, Y.; Ikeda, Y.; Iijima, M.; Adachi, M.; Shimamura, T. Inhibitory effect of catechin against the superantigen staphylococcal enterotoxin B (SEB). Arch. Dermatol. Res. 2003, 295, 183-189. [CrossRef] [PubMed]

78. Xu, X.; Zhou, X.D.; Wu, C.D. The tea catechin epigallocatechin gallate suppresses cariogenic virulence factors of Streptococcus mutans. Antimicrob. Agents Chemother. 2011, 55, 1229-1236. [CrossRef] [PubMed]

79. Xu, X.; Zhou, X.D.; Wu, C.D. Tea catechin epigallocatechin gallate inhibits Streptococcus mutans biofilm formation by suppressing gtf genes. Arch. Oral Biol. 2012, 57, 678-683. [CrossRef]

80. Serra, D.O.; Mika, F.; Richter, A.M.; Hengge, R. The green tea polyphenol EGCG inhibits E. coli biofilm formation by impairing amyloid curli fibre assembly and down-regulating the biofilm regulator CsgD via the $\sigma$ E-dependent sRNA RybB. Mol. Microbiol. 2016, 101, 136-151. [CrossRef]

81. Serra, D.O.; Hengge, R. Experimental detection and visualization of the extracellular matrix in macrocolony biofilms. In c-di-GMP Signaling: Methods E Protocols—Methods in Molecular Biology; Sauer, K., Ed.; Humana Press, Springer Nature: New York, NY, USA, 2017; pp. 133-145.

82. Römling, U.; Amikam, D. Cyclic di-GMP as a second messenger. Curr. Opin. Microbiol. 2006, 9, $218-228$. [CrossRef]

83. Jenal, U.; Malone, J. Mechanisms of cyclic-di-GMP signaling in bacteria. Annu. Rev. Genet. 2006, 40, 385-407. [CrossRef] [PubMed]

84. Hengge, R. Principles of cyclic-di-GMP signaling. Nat. Rev. Microbiol. 2009, 7, 263-273. [CrossRef] [PubMed]

85. Jenal, U.; Reinders, A.; Lori, C. Cyclic-di-GMP: Second messenger extraordinaire. Nat. Rev. Microbiol. 2017, 15, 271-284. [CrossRef] [PubMed]

86. Schirmer, T. C-di-GMP synthesis: Structural aspects of evolution, catalysis and regulation. J. Mol. Biol. 2016, 428, 3683-3701. [CrossRef] [PubMed]

87. Ehrnhoefer, D.E.; Bieschke, J.; Boeddrich, A.; Herbst, M.; Masino, L.; Lurz, R.; Engemann, S.; Pastore, A.; Wanker, E.E. EGCG redirects amyloidogenic polypeptides into unstructured, off-pathway oligomers. Nat. Struct. Mol. Biol. 2008, 15, 558-566. [CrossRef] [PubMed]

88. Bieschke, J.; Russ, J.; Friedrich, R.P.; Ehrnhoefer, D.E.; Wobst, H.; Neugebauer, K.; Wanker, E.E. EGCG remodels mature alpha-synuclein and amyloid-beta fibrils and reduces cellular toxicity. Proc. Natl. Acad. Sci. USA 2010, 107, 7710-7715. [CrossRef] [PubMed]

89. Lopez del Amo, J.M.; Fink, U.; Dasari, M.; Grelle, G.; Wanker, E.E.; Bieschke, J.; Reif, B. Structural properties of EGCG-induced, nontoxic Alzheimer's Disease Aß oligomers. J. Mol. Biol. 2012, 421, 517-524. [CrossRef] [PubMed]

90. Ferreira, N.; Saraiva, M.J.; Almeida, M.R. Epigallocatechin-3-gallate as a potential therapeutic drug for TTR-related amyloidosis: "in vivo" evidence from FAP mice models. PLoS ONE 2012, 7, e29933. [CrossRef] [PubMed]

91. Sirk, T.W.; Brown, E.F.; Sum, A.K.; Friedman, M. Molecular dynamics study on the biophysical interactions of seven green tea catechins with lipid bilayers of cell membranes. J. Agric. Food Chem. 2008, 56, 7750-7758. [CrossRef]

92. Kajiya, K.; Kumazawa, S.; Naito, A.; Nakayama, T. Solid-state NMR analysis of the orientation and dynamics of epigallocatechin gallate, a green tea polyphenol, incorporated into lipid bilayers. Magn. Reson. Chem. 2008, 46, 174-177. [CrossRef]

93. Cui, Y.; Oh, Y.J.; Lim, J.; Youn, M.; Lee, I.; Pak, H.K.; Park, W.; Jo, W.; Park, S. AFM study of the differential inhibitory effects of the green tea polyphenol (-)-epigallocatechin-3-gallate (EGCG) against Gram-positive and Gram-negative bacteri. Food Microbiol. 2012, 29, 80-87. [CrossRef] [PubMed]

94. Vogel, J.; Papenfort, K. Small non-coding RNAs and the bacterial outer membrane. Curr. Opin. Microbiol. 2006, 9, 605-611. [CrossRef] [PubMed]

95. Grabowicz, M.; Silhavy, T.J. Envelope stress responses: An interconnected safety net. Trends Biochem. Sci. 2017, 42, 232-242. [CrossRef] [PubMed]

96. Holmqvist, E.; Wagner, E.G.H. Impact of bacterial sRNAs in stress responses. Biochem. Soc. Trans. 2017, 45, 1203-1212. [CrossRef] [PubMed]

97. Fröhlich, K.S.; Gottesman, S. Small regulatory RNAs in the enterobacterial response to envelope damage and oxidative stress. Microbiol. Spectr. 2018, 6. [CrossRef] [PubMed]

98. Zhao, W.H.; Hu, Z.Q.; Hara, Y.; Shimamura, T. Inhibition of epigallocatechin gallate (EGCg) of conjugative R plasmid transfer in Escherichia coli. J. Infect. Chemother. 2001, 7, 195-197. [CrossRef] 
99. Stenvang, M.; Dueholm, M.S.; Vad, B.S.; Sevlour, T.; Zeng, G.; Gelfman-Shochat, S.; Søndergaard, M.T.; Christiansen, G.; Meyer, R.L.; Kjelleberg, S.; et al. Epigallocatechin gallate remodels overexpressed functional amyloids in Pseudomonas aeruginosa and increases biofilm susceptibility to antibiotic treatment. J. Biol. Chem. 2016, 291, 26540-26553. [CrossRef]

100. Turner, K.H.; Everett, J.; Trivedi, U.; Rumbaugh, K.P.; Whiteley, M. Requirements for Pseudomonas aeruginosa acute burn and chronic surgical wound infection. PLoS Genet. 2014, 10, e1004518. [CrossRef]

101. Marinelli, P.; Pallares, I.; Navarro, S.; Ventura, S. Dissecting the contribution of Staphylococcus aureus a-phenol-soluble modulins to biofilm amyloid structure. Sci. Rep. 2016, 6, 34552. [CrossRef] [PubMed]

102. Kirketerp-Møller, K.; Jensen, P.Ø.; Fazli, M.; Madsen, K.G.; Pedersen, J.; Moser, C.; Tolker-Nielsen, T.; Høiby, N.; Givskov, M.; Bjarnsholt, T. Distribution, organization, and ecology of bacteria in chronic wounds. J. Clin. Microbiol. 2008, 46, 2717-2722. [CrossRef] [PubMed]

103. Fazli, M.; Bjarnsholt, T.; Kirketerp-Møller, K.; Jørgensen, B.; Andersen, A.S.; Krogfelt, K.A.; Givskov, M.; Tolker-Nielsen, T. Nonrandom distribution of Pseudomonas aeruginosa and Staphylococcus aureus in chronic wounds. J. Clin. Microbiol. 2009, 47, 4084-4089. [CrossRef] [PubMed]

104. Serra, S.; Grande, R.; Butrico, L.; Rossi, A.; Settimio, U.F.; Caroleo, B.; Amato, B.; Gallelli, L.; de Franciscis, S. Chronic wound infections: The role of Pseudomonas aeruginosa and Staphylococcus aureus. Expert Rev. Anti Infect. Ther. 2015, 13, 605-613. [CrossRef] [PubMed]

105. Ito, A.; Taniuchi, A.; May, T.; Kawata, K.; Okabe, S. Increased antibiotic resistance of Escherichia coli in mature biofilms. Appl. Environ. Microbiol. 2009, 75, 4093-4100. [CrossRef] [PubMed]

106. Ciofu, O.; Rojo-Molinero, E.; Macià, M.D.; Oliver, A. Antibiotic treatment of biofilm infections. Acta Pathol. Microbiol. Immunol. Scand. 2017, 125, 304-319. [CrossRef] [PubMed]

107. Mah, T.F.; O’Toole, G.A. Mechanisms of biofilm resistance to antimicrobial agents. Trends Microbiol. 2001, 9, 34-39. [CrossRef]

108. Mah, T.F.; Pitts, B.; Pellock, B.; Walker, G.C.; Stewart, P.S.; O’Toole, G.A. A genetic basis for Pseudomonas aeruginosa biofilm antibiotic resistance. Nature 2003, 426, 306-310. [CrossRef]

109. Kai-Larsen, Y.; Lüthje, P.; Chromek, M.; Peters, V.; Wang, X.; Holm, A.; Kádas, L.; Hedlund, K.O.; Johansson, J.; Chapman, M.R.; et al. Coli modulates immune responses and its curli fimbriae interact with the antimicrobial peptide LL-37. PLoS Pathog. 2010, 6, e1001010. [CrossRef]

110. Hobley, L.; Harkins, C.; MacPhee, C.E.; Stanley-Wall, N.R. Giving structure to the biofilm matrix: An overview of individual strategies and emerging common themes. FEMS Microbiol. Rev. 2015, 39, 649-669. [CrossRef]

111. Peterson, B.W.; He, Y.-Q.; Ren, Y.; Zerdoum, A.; Libera, M.R.; Sharma, P.K.; van Winkelhoff, A.-J.; Neut, D.; Stoodley, P.; van der Mei, H.C.; et al. Viscoelasticity of biofilms and their recalcitrance to mechanical and chemical challenges. FEMS Microbiol. Rev. 2015, 39, 234-245. [CrossRef]

112. Walters, M.C.; Roe, F.; Bugnicourt, A.; Franklin, M.J.; Stewart, P.S. Contributions of antibiotic penetration, oxygen limitation, and low metabolic activity to tolerance of Pseudomonas aeruginosa biofilms to ciprofloxacin and tobramycin. Antimicrob. Agents Chemother. 2003, 47, 317-323. [CrossRef]

113. Hengge, R. The general stress response in Gram-negative bacteria. In Bacterial Stress Responses; Storz, G., Hengge, R., Eds.; ASM Press: Washington, DC, USA, 2011; pp. 251-289.

114. Nguyen, D.; Joshi-Datar, A.; Lepine, F.; Bauerle, E.; Olakanmi, O.; Beer, K.; McKay, G.; Siehnel, R.; Schafhauser, J.; Wang, Y.; et al. Active starvation responses mediate antibiotic tolerance in biofilms and nutrient-limited bacteria. Science 2011, 334, 982-986. [CrossRef] [PubMed]

115. Zhang, L.; Mah, T.F. Involvement of a novel efflux system in biofilm-specific resistance to antibiotics. J. Bacteriol. 2008, 190, 4447-4452. [CrossRef] [PubMed]

116. Poudyal, B.; Sauer, K. The ABC of biofilm drug tolerance: The MerR-like regulator BrlR is an activator of ABC transport systems, with PA1874-77 contributing to the tolerance of Pseudomonas aeruginosa biofilms to tobramycin. Antimicrob. Agents Chemother. 2018, 62, e01981-17. [CrossRef] [PubMed]

117. Lewis, K. Multidrug tolerance of biofilms and persister cells. Curr. Top. Microbiol. Immunol. 2008, 322, 107-131.

118. Stewart, P.S.; Franklin, M.J. Physiological heterogeneity in biofilms. Nat. Rev. Microbiol. 2008, 6, $199-210$. [CrossRef]

119. Monds, R.D.; O'Toole, G.A. The developmental model of microbial biofilms: Ten years of a paradigm up for review. Trends Microbiol. 2009, 17, 73-87. [CrossRef] [PubMed] 
120. Klauck, G.; Serra, D.O.; Possling, A.; Hengge, R. Spatial organization of different sigma factor activities and c-di-GMP signalling within the three-dimensional landscape of a bacterial biofilm. Open Biol. 2018, 8, 180066. [CrossRef]

121. Shiota, S.; Shimizu, M.; Mizushima, T.; Ito, H.; Hatano, T.; Yoshida, T.; Tsuchiya, T. Marked reduction in the minimum inhibitory concentration (MIC) of beta-lactams in methicillin-resistent Staphylococcus aureus produced by epicatechine gallate, an ingredient of green tea (Camellia sinensis). Biol. Pharm. Bull. 1999, 22, 1388-1390. [CrossRef]

122. Hu, Z.-Q.; Zhao, W.-H.; Hara, Y.; Shimamura, T. Epigallocatechin gallate synergy with ampicillin/sulbactam against 28 clinical isolates of methicillin-resistant Staphylococcus aureus. J. Antimicrob. Chemother. 2001, 48, 361-364. [CrossRef]

123. Hu, Z.-Q.; Zhao, W.-H.; Asano, N.; Yoda, Y.; Hara, Y.; Shimamura, T. Epigallocatechin gallate synergistically enhances the activity of carbapenems against methicillin-resistant Staphylococcus aureus. Antimicrob. Agents Chemother. 2002, 46, 558-560. [CrossRef]

124. Zhao, W.H.; Hu, Z.Q.; Hara, Y.; Shimamura, T. Inhibition of penicillinase by epigallocatechin gallate resulting in restoration of antibacterial activity of penicillin against penicillinase-producing Staphylococcus aureus. Antimicrob. Agents Chemother. 2002, 46, 2266-2268. [CrossRef] [PubMed]

125. Dey, D.; Ghosh, S.; Ray, R.; Hazra, B. Polyphenolic secondary metabolites synergize the activity of commercial antibiotics against clinical isolates of b-lactamase-producing Klebsiella pneumoniae. Phytother. Res. 2016, 30, 272-282. [CrossRef] [PubMed]

126. O'May, C.; Ciobanu, A.; Lam, H.; Tufenkji, N. Tannin derived materials can block swarming motility and enhance biofilm formation in Pseudomonas aeruginosa. Biofouling 2012, 28, 1063-1076. [CrossRef] [PubMed]

127. Bikels-Goshen, T.; Landau, E.; Saguy, S.; Shapira, R. Staphylococcal strains adapted to epigallocathechin gallate (EGCG) show reduce susceptibility to vancomycin, oxacillin and ampicillin, increased heat tolerance, and altered cell morphology. Int. J. Food Microbiol. 2010, 138, 26-31. [CrossRef] [PubMed]

128. Ide, K.; Matsuoka, N.; Yamada, H.; Furushima, D.; Kawakami, K. Effects of tea catechins on Alzheimer's Disease: Recent updates and perspectives. Molecules 2018, 23, 2357. [CrossRef] [PubMed]

129. Pervin, M.; Unno, K.; Ohishi, T.; Tanabe, H.; Miyoshi, N.; Nakamura, Y. Beneficial effects of green tea catechins on neurodegenerative diseases. Molecules 2018, 23, 1297. [CrossRef] [PubMed]

130. Shirakami, Y.; Shimizu, M. Possible mechanisms of green tea and its constituents against cancer. Molecules 2018, 23, 2284. [CrossRef] [PubMed]

131. Reto, M.; Figueira, M.E.; Filipe, H.M.; Almeida, C.M. Chemical composition of green tea (Camellia sinensis) infusions commercialized in Portugal. Plant Foods Hum. Nutr. 2007, 62, 139-144. [CrossRef]

132. Solovchenko, A.; Schmitz-Eiberger, M. Significance of skin flavonoids for UV-B-protection in apple fruits. J. Exp. Bot. 2003, 54, 1977-1984. [CrossRef]

133. Matern, U.; Kneusel, R.E. Phenolic compounds in plant disease resistance. Phytoparasitica 1988, 16, $153-170$. [CrossRef]

134. Field, B.; Jordán, F.; Osbourn, A. First encounters-Deployment of defence-related natrual products by plants. New. Phytol. 2006, 172, 193-207. [CrossRef] [PubMed]

135. Ullah, C.; Unsicker, S.B.; Fellenberg, C.; Constabel, C.P.; Schmidt, A.; Gershenzon, J.; Hammerbacher, A. Flavan-3-ols are an effective chemical defense against rust infection. Plant Physiol. 2017, 175, 1560-1578. [CrossRef] [PubMed]

136. Teplitski, M.; de Moraes, M. Of mice and men... and plants: Comparative genomics of the dual lifestyles of enteric pathogens. Trends Microbiol. 2018, 26, 748-754. [CrossRef] [PubMed]

137. Storz, G.; Hengge, R. Bacterial Stress Responses; ASM Press: Washington, DC, USA, 2011.

138. Vorholt, J.A. Microbial life in the phyllosphere. Nat. Rev. Microbiol. 2012, 10, 828-840. [CrossRef] [PubMed]

139. Yaron, S.; Römling, U. Biofilm formation by enteric pathogens and its role in plant colonization and persistence. Microb. Biotechn. 2014, 7, 496-516. [CrossRef] [PubMed]

140. Barak, J.D.; Gorski, L.; Naraghi-Arani, P.; Charkowski, A.O. Salmonella enterica virulence genes are required for bacterial attachment to plant tissue. Appl. Environ. Microbiol. 2005, 71, 5685-5691. [CrossRef]

141. Jeter, C.; Matthysse, A.G. Characterization of the binding of diarrheagenic strains of E. coli to plant surfaces and the role of curli in the interaction of the bacteria with alfalfa sprouts. Mol. Plant Microbe Interact. 2005, 18, 1235-1242. [CrossRef] [PubMed] 
142. Matthysse, A.G.; Deora, R.; Mishra, M.; Torres, A.G. Polysaccharides cellulose, poly-beta-1,6-n-acetyl-D-glucosamine, and colanic acid are required for optimal binding of Escherichia coli O157:H7 strains to alfalfa sprouts and K-12 strains to plastic but not for binding to epithelial cells. Appl. Environ. Microbiol. 2008, 74, 2384-2390. [CrossRef]

143. Saldana, Z.; Sánchez, E.; Xicohtencatl-Cortes, J.; Puente, J.L.; Girón, J.A. Surface structure involved in plant stomata and leaf colonization by Shiga-toxigenic Escherichia coli O157:H7. Front. Microbiol. 2011, 2, 119. [CrossRef]

144. Fink, R.C.; Black, E.P.; Hou, Z.; Sugawara, M.; Sadowsky, M.J.; Diez-Gonzalez, F. Transcriptional responses of Escherichia coli K-12 and O157:H7 associated with lettuce leaves. Appl. Environ. Microbiol. 2012, 78, 1752-1764. [CrossRef]

145. Macarisin, D.; Patel, J.; Bauchan, G.; Giron, J.A.; Sharma, V.K. Role of curli and cellulose expression in adherence of Escherichia coli O157:H7 to spinach leaves. Foodborne Pathog. Dis. 2012, 9, 160-167. [CrossRef] [PubMed]

146. Jones, J.D.; Dangl, J.L. The plant immune system. Nature 2006, 444, 323-329. [CrossRef] [PubMed]

147. Bednarek, P.; Osbourn, A. Plant-microbe interactions: Chemical diversity in plant defense. Science 2009, 324, 746-748. [CrossRef] [PubMed]

148. Ahuja, I.; Kissen, R.; Bones, A.M. Phytoalexins in defense against pathogens. Trends Plant Sci. 2012, 17, 73-90. [CrossRef] [PubMed]

149. Piasecka, A.; Jedrzeyczak-Rey, N.; Bednarek, P. Secondary metabolites in plant innate immunity: Conserved function of divergent chemicals. New Phytol. 2015, 206, 948-964. [CrossRef]

150. Radulovic, N.S.; Blagojevic, P.D.; Stojanovic-Radic, Z.Z.; Stojanovic, N.M. Antimicrobial plant metabolites: Structural diversity and mechanism of action. Curr. Med. Chem. 2013, 20, 932-952.

151. Bulgarelli, D.; Schlaeppi, K.; Spaepen, S.; Ver Loren van Thermaat, E.; Schulze-Lefert, P. Structure and functions of the bacterial microbiota of plants. Ann. Rev. Plant Biol. 2013, 64, 807-838. [CrossRef]

152. Rosier, A.; Bishnoi, U.; Lakshmanan, V.; Sherrier, D.J.; Bais, H.P. A perspective on inter-kingdom signaling in plant-beneficial microbe interactions. Plant Mol. Biol. 2016, 90, 537-548. [CrossRef]

153. Chen, D.; Cao, Y.; Yu, L.; Tao, Y.; Zhou, Y.; Zhi, Q.; Lin, H. Characteristics and influencing factors of amyloid fibers in S. mutans biofilm. AMB Expr. 2019, 9, 31. [CrossRef]

154. Du, X.; Huang, X.; Huang, C.; Wang, Y.; Zhang, Y. Epigallocatechin-3-gallate (EGCG) enhances the therapeutic activity of a dental adhesive. J. Dent. 2012, 40,485-492. [CrossRef]

155. Hu, J.; Du, X.; Huang, C.; Fu, D.; Ouyang, X.; Wang, Y. Antibacterial and physical properties of EGCG-containing glass ionomer cements. J. Dent. 2013, 41, 927-934. [CrossRef] [PubMed]

156. Yu, H.H.; Zhang, L.; Yu, F.; Liu, Z.Y.; Chen, J.H. Epigallocatechin-3-gallate and epigallocatechin-3-O-(3-O-methyl)-gallate enhance the bonding stability of an etch-and-rinse adhesive to dentin. Materials 2017, 10, 183. [CrossRef] [PubMed]

157. Yu, J.; Yang, H.; Li, K.; Ren, H.; Lei, J.; Huang, C. Development of epigallocatechin-3-gallate-encapsulated nanohydroxyappatite/mesoprous silica for therapeutic management of dentin surface. ACS Appl. Mater. Interfaces 2017, 9, 25796-25807. [CrossRef] [PubMed]

158. Melok, A.L.; Lee, L.H.; Yussof, S.A.M.; Chu, T. Green tea polyphenol epigallocatechin-3-gallate-stearate inhibits the growth of Streptococcus mutans. A promising new approach in caries prevention. Dent. J. 2018, 6, 38. [CrossRef] [PubMed]

159. Francesko, A.; Soares da Costa, D.; Reis, R.L.; Pashkuleva, I.; Tzanov, T. Functional biopolymer-based matrices for modulation of chronic wound enzyme activities. Acta Biomater. 2013, 9, 5216-5225. [CrossRef] [PubMed]

160. Kim, H.L.; Lee, J.H.; Kwon, B.H.; Lee, M.H.; Han, D.W.; Hyon, S.H.; Park, J.C. Promotion of full-thickness wound healing using epigallocatechin-3-O-gallate/poly (lactic-co-glycolic acid) membrane as temporary wound dressing. Artif. Organs 2014, 38, 411-417. [CrossRef]

161. Li, M.; Xu, J.; Shi, T.; Yu, H.; Bi, J.; Chen, G. Epigallocatechin-3-gallate augments therapeutic effects of mesenchymal stem cells in skin wound healing. Clin. Exp. Pharmacol. Physiol. 2016, 43, 1115-1124. [CrossRef]

162. Huang, Y.W.; Zhu, Q.Q.; Yang, X.Y.; Xu, H.H.; Sun, B.; Wang, X.J.; Sheng, J. Wound healing can be improved by (-)-epigallocatechin gallate through targeting Notch in streptozotocin-induced diabetic mice. FASEB J. 2019, 33, 952-964. [CrossRef] 
163. Ullmann, U. Plasma-kinetic characteristics of purified and isolated green tea catechin epigallocatechin gallate (EGCG) after 10 days repeated dosing in healthy volunteers. Int. J. Vitam. Nutr. Res. 2004, 74, 269-278. [CrossRef]

164. Schantz, M.; Erk, T.; Richling, E. Metabolism of green tea catechins by the human small intestine. Biotech. J. 2010, 5, 1050-1059. [CrossRef]

165. Gan, R.Y.; Li, H.B.; Sui, Z.Q.; Corke, H. Absorption, metabolism, anti-cancer effect and molecular targets of epigallocatechin gallate (EGCG): An updated review. Crit. Rev. Food Sci. Nutr. 2018, 58, 924-941. [CrossRef] [PubMed]

166. Liu, Z.; Bruins, M.E.; Ni, L.; Vincken, J.P. Green and black tea phenolics: Bioavailability, transformation by colonic microbiota, and modulation of colonic microbiota. J. Agric. Food Chem. 2018, 66, 8469-8477. [CrossRef] [PubMed]

167. Bian, Z.; Brauner, A.; Li, Y.; Normark, S. Expression of and cytokine activation by Escherichia coli curli fibres in human sepsis. J. Infect. Dis. 2000, 181, 602-612. [CrossRef] [PubMed]

168. Tükel, C.; Wilson, R.P.; Nishimori, J.H.; Pezeshki, M.; Chromy, B.A.; Bäumler, A.J. Responses to amyloids of microbial and host origin are mediated through toll-like receptor 2. Cell Host Microbe 2009, 6, 45-53. [CrossRef] [PubMed]

169. Tükel, C.; Raffatellu, M.; Humphries, A.D.; Wilson, R.P.; Andrews-Polymenis, H.L.; Gull, T.; Figueiredo, J.F.; Wong, M.H.; Michelsen, K.S.; Akcelik, M.; et al. CsgA is a pathogen-associated molecular pattern of Salmonella enterica serotype Typhimurium that is recognized by Toll-like receptor 2. Mol. Microbiol. 2005, 58, 289-304. [CrossRef] [PubMed]

170. Winter, S.E.; Bäumler, A.J. Dysbiosis in the inflamed intestine: Chance favors the prepared microbe. Gut Microbes 2014, 5, 71-73. [CrossRef] [PubMed]

171. Yang, F.; Oz, H.S.; Barve, S.; De Villiers, W.J.; McClain, C.J.; Varilek, G.W. The green tea polyphenol (-)-epigallocatechin-3-gallate blocks nuclear factor-kappa B activation by inhibiting I kappa B kinase activity in the intestinal epithelial cell line IEC-6. Mol. Pharmacol. 2001, 60, 528-533.

172. Oz, H.S.; Chen, T.; De Villiers, W.J. Green tea polyphenols and sulfasalazine have parallel anti-inflammatory properties in colitis models. Front. Immunol. 2013, 4, 132. [CrossRef]

173. Barbalho, S.M.; Bosso, H.; Salzedas-Pescinini, L.M.; de Alvares Goulart, R. Green tea: A possibility in the therapeutic approach of inflammatory bowel diseases? Green tea and inflammatory bowel diseases. Complement. Ther. Med. 2019, 43, 148-153. [CrossRef]

174. Lecumberri, E.; Dupertuis, Y.M.; Miralbell, R.; Pichard, C. Green tea polyphenol epigallocatechin-3-gallate (EGCG) as adjuvant in cancer therapy. Clin. Nutr. 2013, 32, 894-903. [CrossRef]

175. Hara-Terawaki, A.; Takagaki, A.; Kobayashi, H.; Nanjo, F. Inhibitory activity of catechin metabolites produced by intestinal microbiota on proliferation of HeLa cells. Biol. Pharm. Bull. 2017, 40, 1331-1335. [CrossRef]

176. Zhang, S.; Zhao, Y.; Ohland, C.; Jobin, C.; Sang, S. Microbiota facilitates the formation of the aminated metabolite of green tea polyphenol (-) epigallocatechin-3-gallate which tap deleterious reactive endogeneous metabolites. Free Radic. Biol. Med. 2019, 131, 332-344. [CrossRef] [PubMed]

177. Gil-Cardoso, K.; Ginés, I.; Pinent, M.; Ardévol, A.; Blay, M.; Terra, X. Effects of flavonoids on intestinal inflammation, barrier integrity and changes in gut microbiota during diet-induced obesity. Nutr. Res. Rev. 2016, 29, 234-248. [CrossRef] [PubMed]

178. Remely, M.; Ferk, F.; Sterneder, S.; Setayesh, T.; Roth, S.; Kepcija, T.; Noorizadeh, R.; Rebhan, I.; Greunz, M.; Beckmann, J.; et al. EGCG prevents high fat diet-induced changes in gut microbiota, decreases of DNA strand breaks, and changes in expression and DNA methylation of Dnmt1 and MLH1 in C57BL/6J male mice. Oxid. Med. Cell. Longev. 2017, 3079148. [CrossRef] [PubMed]

179. Sheng, L.; Jena, P.K.; Liu, H.X.; Hu, Y.; Nagar, N.; Bronner, D.N.; Settles, M.L.; Bäumler, A.J.; Wan, Y.Y. Obesity treatment by epigallocatechin-3-gallate-regulated bile acid signaling and its enriched Akkermansia muciniphila. FASEB J. 2018, 32, 6371-6384. [CrossRef] [PubMed]

(C) 2019 by the author. Licensee MDPI, Basel, Switzerland. This article is an open access article distributed under the terms and conditions of the Creative Commons Attribution (CC BY) license (http://creativecommons.org/licenses/by/4.0/). 